\title{
Prospects of Nutritional Interventions in the Care of COVID-19 Patients
}

SabihaAlam ${ }^{1, \&}$, FarhanaRumzum Bhuiyan ${ }^{2,3, \& *}$, Tanvir Hossain Emon ${ }^{4}$, MahmudulHasan $^{5 *}$

${ }^{1}$ Institute of Nutrition and Food Science, University of Dhaka, Bangladesh

${ }^{2}$ Department of Botany, University of Chittagong, Chittagong, Bangladesh

${ }^{3}$ Laboratory of Biotechnology and Molecular biology, Department of Botany, University of

Chittagong, Chittagong, Bangladesh

${ }^{4}$ Department of Genetic Engineering and Biotechnology, Shahjalal University of Science and

Technology, Sylhet, Bangladesh.

${ }^{5}$ Department of Pharmaceuticals and Industrial Biotechnology, Sylhet Agricultural University,

Sylhet, Bangladesh

${ }^{\&}$ Authors Sabiha Alam and Farhana Rumzum Bhuiyan contributed equally to this work

\section{*Corresponding Authors:}

Farhana Rumzum Bhuiyan*

Department of Botany

University of Chittagong

Chittagong, Bangladesh

Email: farhana.bot@cu.ac.bd;

Tel: 8801816515140; Fax: 88031-726310
Mahmudul Hasan*

Department of Pharmaceuticals and Industrial Biotechnology

Sylhet Agricultural University, Sylhet, Bangladesh

Email: mhasan.pib@sau.ac.bd

Tel: 8801723698461 


\title{
Prospects of Nutritional Interventions in the Care of COVID-19 Patients
}

\begin{abstract}
The novel coronavirus diseases 2019 (COVID-19) has unfolded an unprecedented worldwide public health emergency with disastrous economic consequences. Around 12 million coronavirus cases have already been identified with over half a million deaths. Despite numerous efforts by the government as well as international organizations, these numbers are still increasing with a surprising rate. Although urgent and absolutely necessary, a reliable therapeutic or vaccine is still elusive and this status quo may remain for an uncertain period of time. Taken that into account, boosting up adaptive immunity through nutritional interventions may help subside this epidemic and save many lives. This review focuses on the nexus between a balanced diet and adaptive immunity, particularly, how a poor diet may lead to compromised immunity resulting in susceptibility to viral infections. Additionally, we discuss how nutrients (vitamins, minerals, trace elements) could be used as a tool to modulate immune response and thus impede viral infections. The study also summarized nutritional recommendations to combat COVID-19 in different countries and territories and dietary sources of those key nutrients. Moreover, different nutritional intervention strategies based on different age groups, physiological and medical conditions were also included, and the challenges of nutritional interventions towards the care of COVID-19 patients were also discussed. Since the availability of a drug or vaccine is still uncertain, a balanced diet or nutrient therapy could be used as a robust strategy to combat COVID-19. Thus, we hope this review may help to make an informed decision with regard to diet choice both at individual level as well as clinical settings.
\end{abstract}

Keywords: Macronutrients; Micronutrients; COVID-19; SARS-CoV-2; Immunity; Complications; 


\section{Background}

COVID-19 is a deadly respiratory disease caused by a newly emerged coronavirus which was first detected in Wuhan, China during December 2019 [1]. Within a few days, several patients from Wuhan, China were admitted to the hospitals showing some common symptoms of pneumonia [2]. Now, it has been spread around 215 countries with its pandemic notion [3]. As a consequence of rapid transmission, WHO declared immediately a public health emergency of international concern (PHEIC) alarm on January 30,2020. Coronavirus is not newly appeared indeed, rather in 2003, the severe acute respiratory syndrome (SARS) outbreak appeared in another state of China (Guangdong, southern China) for 8000 cases and resulted in 800 deaths in 26 countries and characterized as SARS CoV. Later on, in September 2012, MERS-CoV (Middle East respiratory syndrome coronavirus) associated deaths were reported in 858 cases. The disease, novel coronavirus (2019-nCoV) transmission occurred due to SARS-CoV-2 (severe acute respiratory syndrome coronavirus 2) [4,5]. Mathematical modeling analysis estimated the basic reproductive number $\mathrm{R}_{0}$ of the SARS-CoV-2 in the range of 2.24 to 3.58 with mean incubation period of 6.4 days [6,7]. The $\mathrm{R}_{0}$ higher than 1 implies that the transmission can occur continuously causes an epidemic or pandemic if left uncontrolled. Even though the mortality rate is much lower than that of SARS (10.87\%) and MERS (34.4\%), the highly contagious SARS-CoV-2 confirmed cases around the globe after 6 months of emergence is alarming [8,9]. Immunocompromised people such as elderly ones, underrepresented minorities and the ones with pre-existing comorbidities are in the high risk groups of infection ${ }^{22}$. Moreover, like SARS and MERS-CoV, SARS-CoV-2 coronavirus is presumed to escape human immune detection at the initial stage of infection and may dampen the immune function. The vaccine trials for SARSCoV-2 are going on with some positive results in some developing and developed countries but a certified vaccine is not available yet. In this context, enhancing the body's immune system to combat the disease till launching of an effective vaccine is necessary. However, in an organism, the immune system is a key performer that compromises defense not only for the common diseases and health complications like abnormal cell development and cancers, arthritis, allergies, but also from pathogenic infections by bacteria [10] and viruses including novel coronavirus (COVID-19). The immune defense system uses numerous plasma proteins (blood proteins, Immunoglobulin G (IgG), hemopexin (heme-binding protein) to modulate the immune response [11]. Besides, great nourishment is fundamental to build a strong immune system whereas malnutrition, a global problem considered as the most predominant cause of immunodeficiency worldwide [12,13]. In that case, a balanced diet can ensure proper nutrition (carbohydrate, protein, fat, fiber, vitamins, and minerals) which is essential to strong immunity [14]. Diet is a particular selection of food and drink which is 
regularly consumed by a person to improve one's physical condition to prevent or treat a disease and thus assist to keep an individual mentally and physically healthy whereas a balanced diet includes distinct food groups in certain quantities and proportions to fulfill the requirement for calories, proteins, minerals and vitamins. There is no alternative to a balanced diet to keep ourselves physically and mentally fit.

Immunity refers to the capability of the organism to fight the attack of microbes and harmful substances [15]. Lack of a balanced diet, poor socioeconomic conditions, health complications, irregularity in physical activities, environmental pollution all together lead to poor diet followed by compromised immune systems (Figure 1) which ultimately results in an increased risk of infection by pathogens [16]. Hence, taking a healthy diet, ensuring proper nutrition, and maintaining social distance can be the best way as preventive methods to win the battle against the SARS CoV-2. Several researchers are more focusing on the modification of diet to treat the deadly COVID-19 worldwide. Nutritional interventions can work well in this regard to save people from unexpected health complications and deaths. Therefore, this review attempted to know about the potential role ofnutrients of different food groups with their antiviral properties to increase immunity against viral infection including SARS CoV-1 and other RNA viruses by making people able to make a right diet choice in pandemic as well as post pandemic situation.

\section{Global needs of nutritional interventions towards the COVID-19 pandemic}

Since its emergence in Wuhan, the COVID-19 infection is spreading alarmingly infecting a huge number of people. Across 32 different locations around the world, the median infection fatality rate was $0.27 \%$ till July, 2020[17]. Although the viral transmission was supposed to be linked with the trade animals in the market, there is no conclusive evidence of animal association to date with the COVID-19 infection [18]. However several reports confirmed human to human transmission of this virus through respiratory droplets or close contact with the affected ones [19,20]. Asymptomatic viral shedding has caused more severity of this contagious disease leading to high risk of infection [20]. The elderly people are more prone to infection compared to the young and young adult ones due to shrinkage of naïve $\mathrm{T}$ cells for prolonged antigen encounters [21]. Moreover the peoples having comorbidities with diabetes, hypertension and other cardiovascular and cerebrovascular diseases are more likely to be affected in a severe way than healthy population [22,23,24,25].

SARS-CoV-2 virus can be latent for about 2-14 days in the host leading to non-severe symptomatic infection to acute respiratory distress syndrome (ARDS) with high viral load [26,27]. The virus 
enters into the body by binding its spike protein with angiotensin-converting enzyme 2 (ACE2) cell receptor predominantly found in the respiratory cells [28]. Type I IFN (IFN-I) response and its downstream cascade plays a crucial role in counteracting the viral replication by inducing the adaptive immune system to produce antibody and memory cells. SARS-CoV viruses can block the IFN induction leading to the dysregulation of the immune system which results in cytokine storm and eventually death [29]. Severe hypercytokinemia or cytokine storm cases were reported in China, Italy, USA, Spain, Brazil and many other countries. As there is no effective treatment available for the disease, boosting immune response in the preliminary asymptomatic stage is crucial to maintain a good health.Long time and consistent healthy dietary pattern is the key determinant of sound health. On the contrary, unhealthy diet and lifestyle promotes the development of non-communicable diseases like diabetes, cardiovascular disease and chronic respiratory disease has negative impact on prognosis of COVID-19 [30]. An ideal nutritional condition is the prerequisite for regulating the oxidative stress and inflammatory process which ultimately have impact on immune system [31]. Nutrition deficiency resulted in different complications which act as negative prognosis factor in COVID-19 patients. Low pre-albumin level in circulating blood marks malnutrition, which is a potential predictor for the prognosis of COVID patients to the acute respiratory problems leading to the ventilation [32]. Lymphocytopenia, a malnutrition marker, has been observed mostly in nonsurvivor patients than the survivor ones. Obesity caused by consumption of food high in saturated fat, sugar and carbohydrate has link to high mortality and increase risk to influenza-related complications. Obese and obese like diabetic patient exhibits weaker immune response during antigen presentation due to reduced macrophage activation and cause increased susceptibility to viral infection [33]. Therefore, the nutritional interventions could be an efficient strategy to boost up the overall immunity or health conditions of normal people who further could be able to combat against COVID-19 infection.

\section{Viral susceptibility and common complications associated with nutrient deficiencies}

The immune system comprises two lines of defense including innate immunity and adaptive immunity [34]. Innate immunity is the rapid immunological, non-specific mechanism to protect the host from an invading pathogen [35] whereas adaptive immunity is the antigen-specific mechanism against virus infection [36]. The virus interaction with the host and spreading strategy of the virus decides the immune response of a patient basically [37]. The viral antigens can be present in various parts of the body depending on the spreading route and infection stage in the patient. Besides, the host has diverse immune defense functions (humoral immunity through $\operatorname{IgA}$ and cell-mediated 
immunity can eliminate local viral infections). Humoral immunity stimulates B lymphocytes to produce viral antigen-specific antibodies [38,39]. Virus recognition by leukocytes of virus-infected cells, cytokines (growth factors that are secreted by certain cells of the immune system) production is stimulated by the virus-infected cells or the virus [40]. Few cells like natural killer (NK) cells, cytotoxic T lymphocytes, and macrophages can identify and kill virus-infected cells. Helper T cells can also identify virus-infected cells and produce numerous essential cytokines [41,42]. Cytokines produced by monocytes (monokines), T cells, and natural killer cells (lymphocytes) play vital roles to regulate immune functions and develop antiviral immune functions [43] (Figure 2). However, the nutritional status of a person has an impact on immune cell metabolism and function [44].

Besides, sufficient intake of carbohydrate aids to maintain stable blood sugar level and reduces body's stress response by modifying the undesirable mobilization of immune cells [45]. Moreover, the severity of protein deficiency affects the mechanisms of primary lymphoid organs (bone marrow, thymus) leading them to generate B and T cell repertoires and reduces the generation of IL-6 and TNF-Alpha by bone marrow cells [46,47]. Vitamins and minerals help optimizing the innate immunity through development, differentiation and chemotaxis of innate cells; activating macrophage and neutrophils killing property and producing antimicrobial proteins. These nutrients also have pleiotropic effect on adaptive immunity and foster the immune function via antibody production and memory cell generation [48].Deficiency of nutrients, whether they are macronutrients (carbohydrates, protein, fat) or micronutrients (vitamins, minerals, trace elements) can lead to impaired immune systems [49] and can increase the risk of bacterial and viral attack [50,51,52]. Moreover, inadequate macronutrients or selected micronutrients, especially vitamins and the minerals magnesium, iron, zinc, selenium can lead to clinically significant immune deficiency and infections in humans [53]. For example, vitamin $\mathrm{C}$ deficiency had been reported for susceptibility to respiratory infections like Pneumonia [54]. Similarly, low level of 25-hydroxyvitamin D, a major vitamin D metabolite have found association with acute respiratory tract infection [55].On the contrary, different micronutrients can be achieved from our daily food which can help reduce inflammation, improve immunity due to their antiviral activities [56,57,58]. Vitamins and minerals help optimizing innate immunity by production, differentiation and chemotaxis of innate immune cells and activating macrophage. Common health complications associated with nutrient deficiencies were enlisted in the Table 1 [59-75]. 


\section{Food nutrients with antiviral activities suggested for COVID-19}

Coronavirus is considered the worst ever health disaster in the recent eras. Nutrients being classified into two major groups such as macronutrients and micronutrients, play a cornerstone role in human body. Macronutrients considered as the energy-providing nutrients like carbohydrates, protein, fat and dietary fiber are needed to be consumed in larger quantities ( $g$ ) as theyregulate regular life processes (growth, development, repair of tissues). Micronutrients are minerals and vitamins which are required in very tiny amounts [76,77]. Albeit, together both are extremely important for the normal body functioning in human body [78,79]. They are involved in triggering many important biochemical reactions for example- works as cofactors and coenzymes in metabolism $[80,81,82,83]$. However, micronutrients are getting large attention all over the world during the COVID-19 pandemic for its ability to alter the susceptibility to infection $[84,85,86]$. Cytokines (certain cells secreted substances that affect other cells) lead to inflammation through damaging the lining of the lungs, leading to pneumonia. Vitamins and cytokines has the ability to modulate immunity and inflammation as well. Immunity involves vitamins renovate the capability of some cells to produce certain cytokines that affect the mechanism of immune cells [87]. Vitamin E is indispensable to get rid of chronic viral infections [88]. Different water-soluble vitamins like vitamin B complexes, vitamin $\mathrm{C}$, and fat-soluble vitamins (Vitamin A, vitamin D, vitamin E), different trace elements (Zinc, Magnesium, Iron, Selenium) have been proved to show the satisfactory effect on enhancing human immune response. Adequacy of iron can protect from the respiratory tract infections in severely critically infected coronavirus patients. Essential fatty acids such as omega-3 fatty acids that modulate immune function by its action on inflammatory response [89]. Magnesium is associated with the immune system in both innate and acquired responses. It acts as a cofactor for participation in immunoglobulin synthesis and antibody production. Magnesium is the most overlooked electrolyte, although it has an enormous role in immune function [90].Hence, the good nutritional status of the host plays a crucial role to deal with different infectious diseases [91]. Therefore, proper nutrition must be ensured to deal with the unexpected infections of the patients who are vulnerable or who have already been attacked by the novel coronavirus. If through diet, the daily required amount of different nutrients are not met, different processed food, and fortified with different nutrients can be approached to ensure a healthy lifestyle. Literature studiesfound a significant role of some food nutrients to tackle a few harmful RNA viruses including SARS viruses through boosting up immunity, and these were presented meticulously in the Table 2 [92-100]. 


\section{Nutritional intervention strategies during COVID-19 pandemic}

Nutritional intervention is a planned action that could be implemented to bring out a beneficial alteration in nutrition-related behavior; health condition for a person, a target groupora group of people playing a key role to combat deadly diseases like coronavirus disease [107]. During the coronavirus pandemic outbreak in China, initially, the aged individuals were infected mostly. Although at the very beginning of the COVID-19 outbreak, there was a lower rate of infection among infants and neonates, gradually, through mutation the virus, it has been changing the genetic material, attacking infants and causing human deaths over time. Development of immune responses varies among different age groups along with gender, physiological conditions and activities [108]. The older malnourished adults are more likely to have inferior health outcomes, longer hospital stays, and increased mortality rate. Therefore, the effective defensive strategies to promote good nutrition among older populations are desired [109,110]. A study showed that different factors for instance: aging, immunity, virus infection fatality rate are strongly interlinked in human body [111]. The innate, immature, and adaptive immune system, which matures and acquires memory, goes into a decline in adulthood followed by the risks of various kinds of infection [109]. However, vitamin C, vitamin A, vitamin D, Zinc, Iron, Magnesium, vitamin b-12 are using to treat coronavirus patients worldwide with a hope of saving million lives. Literature searches found the application of nutritional interventions (mostly of vitamin C and vitamin D) in few countries like China, Italy, the USA and Iran, and some other countries are also taking into accountthe application of those nutrients on coronavirus patients seriously (Table 3) [112-120].

However, there are three types of nutritional intervention which are proposed worldwide to resolve nutrition problems: 1) dietary approaches, 2) fortified and 3) supplementary. Modification of diet might be one of the best approaches. Due to the safety, cost-effectiveness and efficiency for assisting human immune system to combat against COVID-19, dietary supplementation is getting worldwide attention. In a recent RCT study in USA, a decrease in mortality rate was observed when 167 patients with sepsis-related ARAS were given $15 \mathrm{mg} /$ day IV vitamin C [121]. In a multi-nominal logistic regression model, a retrospective study conducted on 212 people in Philippine showed a significant association of serum vitamin D status with COVID-19 patients' clinical outcomes [122]. People who are more prone to Influenza or COVID-19, should take 10,000 IU/d vitamin D3 doses for a several weeks to increase serum 25(OH) D concentrations, followed by 5000 IU/d [123]. Vitamin E, being an antioxidant, it can reduce the rate of inflammation [124].Optimum level of vitamin $\mathrm{E}$ is indispensable to get rid of chronic viral infections [125]. Therefore, vitamin E must be taken in an adequate portion on a regular basis to reduce the possibility of being infected by SARS CoV-2. But, 
unfortunately, vitamin $\mathrm{E}$ got little attention from medical practitioners as a potential nutritional therapy for COVID-19. Vitamin B-complexes also have enormous role to treat COVID-19. Vitamin B3 treatment significantly inhibited neutrophil infiltration into the lungs with a strong antiinflammatory effect during ventilator induced lung injury. Blood coagulation is observed in COVID19 patients leading to deaths [126]. Iron rich food along with vitamin B6 rich food is equally important. Around $70 \%$ Iron found in hemoglobin, which carries oxygen to different cells in human body [127]. Vitamin B6 can introduce a new insight to treat COVID-19 patients. Perhaps, among COVID-19 patients, due to their lower oxygen level, they sometimes face critical phrase [128]. In that case, to level up their oxygen level, consuming functions as a cofactor in hemoglobin synthesis [129]. If our body faces vitamin B6 deficiency, it will directly hamper the hemoglobin synthesis leading to decrease oxygen level in human body. In severe cases, it is one of the main reasons behind million deaths. Vitamin B6 rich could be an alternative solution in that case.In contrast, deficiency of selenium can be the cause of the mutation of innocuous strains of RNA viruses (Influenza virus, Coxsackie viruses) to heavily pathogenic strains [130]. But there is no credible study is done on Selenium to ensure its impact on SARS-CoV-2.Zinc deficiency associated with cardiovascular dysfunction, obesity, diabetes, cancer and age related complications may be considered as a useful treatment due to its antiviral activity and regulation of inflammatory response [131]. Albeit, till to date, no randomized control trial has done to depict the real impact of Zinc on coronavirus patients. However, SARS CoV-2 interferes heme metabolism in human body through attacking 1-beta chain of hemoglobin and finally capturing porphyrin resulting in Iron deficiency [132]. Deficiency of iron has been acknowledged as a remarkable reason behind the development of recurrent acute respiratory tract infections [133]. As a matter of fact, adequacy of iron can play a vital role in the improvement of respiratory tract infections in severely critical infected coronavirus patients. In china, a cohort study of old age people showed positive feedback as most of the patients' demands for oxygen support or intensive care support were reduced [134]. Still, a randomized control trial including a large population is needed to observe the true benefits of those nutrients combination on COVID-19 patients. Supplementation can be applied for adults if their dietary components cannot meet the Recommended Dietary Allowance (Table 4) [135-159].

\section{Challenges towards the nutritional interventions during COVID19 pandemic}

During every pandemic, people all over the world witnessed economic, social and mental pressure from country level to individual level due to sharp decline in GDP growth rate including a drop in 
domestic economic activity, a decline in exports of clothing and a fall in remittances from Bangladeshi living in abroad. Those factors have huge impact on health sector and research as well. No valid medicine or vaccine is yet discovered to treat SARS CoV-2 infected people.COVID-19 pandemic has disrupted the supply chains and instigated financial hardship on distinct logistics companies as well as transportation resulting in poor availability of good nutritional food. COVID-19 has brought out tremendous financial troubles, irrespective of income, people both in developed and developing countries used to eat unhygienic street food, junk food and processed food with high chemicals and preservatives. In contrast, the quarantine during the pandemic induces binge eating among the rich which results in weight gain. Prolonged stay at home reduces physical activity and exposure to sun leading to low vitamin D in the body, one of the most attention seeker nutrient during this pandemic. In that case, modification of diet is the best approach to tackle this pandemic. However, to counteract the negative impact of reduced physical activities, people should refrain themselves from multiple meals a day with a long overnight fast. Avoiding refined sugar and balanced consumption of protein, seeds and vegetables will be helpful to modulate the immune function to fight against inflammation. Older people need to take more protein than the young ones and it is recommended to take at least $1.0 \mathrm{~g} / \mathrm{kg}$ body weight to maintain muscle mass which may increase in presence of chronic illness.Supplementation strategy with vitamins and minerals should be implemented to overcome the malnutrition of aged ones due to inability of ingesting adequate energy with food. But the saddest part is, without income, it is almost impossible to ensure proper nutrition and healthy lifestyle. Several countries around the world used certain nutritional supplementations in clinical settings to assess their true impact on COVID-19 patients. Unfortunately, all of those trials were predominantly carried out in hospital setting with small sample size which followed a cross-sectional prospective design. The first step to battle against COVID-19 is to successfully identify the Corona positive cases. In least developed countries like Bangladesh, even the medical technologists are not enough trained to collect sample in a right way to symbolize the true positive Coronavirus cases, which is one of the biggest challenges. Some essential nutrients for instance- vitamin A, D,E, zinc, vitamin B complexes were used against Avian Coronavirus, Bovine Coronavirus, SARS-CoV and MERS [160], which were mostly responsible for the epidemic occurrences in the past few decades. During the COVID-19 pandemic, a very few of them have been trialed clinically on hospitalized patients, but their biggest limitations were their small cohort and lack of randomized control trials due to lack of funding, time consuming and expensive. Albeit, all of those nutrient supplement trials should be conducted in a large scale to bring out the true exposure and outcome effects. Apart from those, one of the major challenges is the lack of public awareness 
towards taking proper food in a proper quantity and discusses it with dietitians. Especially, in the least developed country like Bangladesh, people mostly depend on the doctors only when there arises any physical complications and food intake related discussions. In a word, the main gaps are mostly correlated to lack of diversified research designs with a priority on both laboratorial and hospital based studies. In a densely populated as well as developing countries like Bangladesh, it is more challenging to improve health sector overnight and increase Corona tests and isolate the positive cases as there is always an economic pressure on the underdeveloped and least developed countries.

\section{Conclusion}

Nutritional interventions play a central role in boosting up immunity and preventing infections among all aged groups. In many cases, a single nutrient deficiency is associated with compromised immunity and increased susceptibility to infections whereas multiple nutrients deficiency may lead to more complex and serious health complications in human body. Dietary modifications such as reduced carbohydrate intake and consuming a small amount of fat in diet than the recommended dietary intake may promote immune system resulting in reduction frequency and severity of infectious diseases. Therefore, dietary strategies could serve as a therapeutic tool to reduce the morbidity and mortality rate caused by COVID-19. In this review, we have accumulated the evidence of different dietary strategies to combat not only this pandemic but also post pandemic situation. In this work, we have found a great consensus that both individual nutrients as well as a combination of multiple nutrients could be supplemented to modulate the severity of COVID-19 at individual level. Furthermore, a community level as well as country level dietary guidelines for at risk populations may help to modulate the trajectory of COVID-19 pandemic both at national and global level. This current work could be used as a resource for different nutrients and their functions, dietary sources and recommended intake for different age groups.

\section{Author Contributions Statement}

$\mathrm{SA}, \mathrm{FRB}$ and $\mathrm{MH}$ initiated this topic and together designed the manuscript structure. SA,THE supported data collection and analysis. SA, FRB and MH finalized the manuscript. SA and FRB two authors contributed equally.

$\mathrm{SA}=$ Sabiha Alam

$\mathrm{FRB}=$ Farhana Rumzum Bhuiyan

THE=Tanvir Hossain Emon 
MH=Mahmudul Hasan

\section{Declaration of Competing Interest}

The authors have declared no conflict of interest.

\section{Footnotes}

The authors did not receive any fund for this study. They reviewed the literatures to get a good insights in food linked to micronutrients and immunology and to deliver the understanding for human welfare as immediate action in response to COVID 19 pandemic situation.

\section{References}

1. Singhal T. (2020). A Review of Coronavirus Disease-2019 (COVID-19). Indian journal of pediatrics, 87(4), 281-286. https://doi.org/10.1007/s12098-020-03263-6

2. Wang D, Hu B, Hu C, et al. Clinical Characteristics of 138 Hospitalized Patients With 2019 Novel Coronavirus-Infected Pneumonia in Wuhan, China. JAMA. 2020; 323(11):1061-1069. doi:10.1001/jama.2020.1585

3. (WHO. Director-General's opening remarks at the media briefing on COVID 19 (2020). https://www.who.int/dg/speeches/detail/who-director-general-s-opening-remarks-at-themedia-briefing-on-covid 19---11-march-2020 [Accessed March 11, 2020]

4. Yan, Y.; Shin, W.I.; Pang, Y.X.; Meng, Y.; Lai, J.; You, C.; Zhao, H.; Lester, E.; Wu, T.; Pang, C.H. The First 75 Days of Novel Coronavirus (SARS-CoV-2) Outbreak: Recent Advances, Prevention, and Treatment. Int. J. Environ. Res. Public Health2020, 17, 2323.

5. Mackenzie, J. S., \& Smith, D. W. (2020). COVID-19: a novel zoonotic disease caused by a coronavirus from China: what we know and what we don't. Microbiology Australia, MA20013. Advance online publication. https://doi.org/10.1071/MA20013

6. Zhao, S., Lin, Q., Ran, J., Musa, S. S., Yang, G., Wang, W., ...\& Wang, M. H. (2020). Preliminary estimation of the basic reproduction number of novel coronavirus (2019-nCoV) in China, from 2019 to 2020: A data-driven analysis in the early phase of the outbreak. International journal of infectious diseases, 92, 214-217. 
7. Wu, J. T., Leung, K., \& Leung, G. M. (2020). Nowcasting and forecasting the potential domestic and international spread of the 2019-nCoV outbreak originating in Wuhan, China: a modelling study. The Lancet, 395(10225), 689-697.

8. https://www.who.int/csr/sars/country/country2003_08_15.pdf?ua=1

9. https://www.who.int/emergencies/mers-cov/en/

10. Machado, Paulo \& Araujo, Maria Ilma\&Carvalho, Lucas \&Carvalho, Edgar. (2004). Mecanismo de respostaimuneàsinfecções. Anais Brasileiros De Dermatologia anBrasildermatol. 79. 10.1590/S0365-05962004000600002.

11. Chaplin D. D. (2010). Overview of the immune response. The Journal of allergy and clinical immunology, 125(2 Suppl 2), S3-S23. https://doi.org/10.1016/j.jaci.2009.12.980

12. Chandra RK. Nutrition and the immune system: an introduction. Am J ClinNutr. 1997; 66(2):460S-463S. doi:10.1093/ajcn/66.2.460S

13. Laviano A., Koverech A., Zanetti M., Nutrition support in the time of SARS-CoV-2 (COVID-19) Nutrition 000 (2020) 110834 editorial.

14. Gleeson M, Nieman DC, Pedersen BK. Exercise, nutrition and immune function. J Sports Sci. 2004; 22(1):115-125. doi:10.1080/0264041031000140590

15. Chaplin D. D. (2010). Overview of the immune response. The Journal of allergy and clinical immunology, 125(2 Suppl 2), S3-S23. https://doi.org/10.1016/j.jaci.2009.12.980

16. Murthy, S., Gomersall, C. D., \& Fowler, R. A. (2020). Care for critically ill patients with COVID-19. Jama.

17. Loannidis, J., (2020). The infection fatality rate of COVID-19 inferred from seroprevalence data. MedRxiV.doi: https://doi.org/10.1101/2020.05.13.20101253

18. 1. Prompetchara, E., Ketloy, C., \&Palaga, T. (2020). Immune responses in COVID-19 and potential vaccines: Lessons learned from SARS and MERS epidemic. Asian Pac J Allergy Immunol, 38(1), 1-9.

19. 2. Chan, J. F. W., Yuan, S., Kok, K. H., To, K. K. W., Chu, H., Yang, J., ... \&Tsoi, H. W. (2020). A familial cluster of pneumonia associated with the 2019 novel coronavirus indicating person-to-person transmission: a study of a family cluster. The Lancet, 395(10223), 514-523. 
20. 3. Li, Q., Guan, X., Wu, P., Wang, X., Zhou, L., Tong, Y., ..\&\& Xing, X. (2020). Early transmission dynamics in Wuhan, China, of novel coronavirus-infected pneumonia. New England Journal of Medicine.

21. 4. Rothe, C., Schunk, M., Sothmann, P., Bretzel, G., Froeschl, G., Wallrauch, C., ...\&Seilmaier, M. (2020). Transmission of 2019-nCoV infection from an asymptomatic contact in Germany. New England Journal of Medicine, 382(10), 970-971.

22. 5. Nikhra, V. (2020). Adverse Outcomes for Elderly in Covid-19: The Loss of the Longevity Dream.

23. 6. Huang, C., Wang, Y., Li, X., Ren, L., Zhao, J., Hu, Y., ...\& Cheng, Z. (2020). Clinical features of patients infected with 2019 novel coronavirus in Wuhan, China. The lancet, 395(10223), 497-506.

24. 7. Chen, N., Zhou, M., Dong, X., Qu, J., Gong, F., Han, Y., ..\& Yu, T. (2020). Epidemiological and clinical characteristics of 99 cases of 2019 novel coronavirus pneumonia in Wuhan, China: a descriptive study. The Lancet, 395(10223), 507-513.

25. 8. Liu, K., Fang, Y. Y., Deng, Y., Liu, W., Wang, M. F., Ma, J. P., ... \& Li, G. C. (2020). Clinical characteristics of novel coronavirus cases in tertiary hospitals in Hubei Province. Chinese medical journal.

26. 9. Guan, W. J., Liang, W. H., Zhao, Y., Liang, H. R., Chen, Z. S., Li, Y. M., ... \&Ou, C. Q. (2020). Comorbidity and its impact on 1590 patients with Covid-19 in China: A Nationwide Analysis. European Respiratory Journal, 55(5).

27. 10. Wang, D., Hu, B., Hu, C., Zhu, F., Liu, X., Zhang, J., ...\& Zhao, Y. (2020). Clinical characteristics of 138 hospitalized patients with 2019 novel coronavirus-infected pneumonia in Wuhan, China. Jama, 323(11), 1061-1069.

28. 11. Lai, C. C., Shih, T. P., Ko, W. C., Tang, H. J., \& Hsueh, P. R. (2020). Severe acute respiratory syndrome coronavirus 2 (SARS-CoV-2) and corona virus disease-2019 (COVID19): the epidemic and the challenges. International journal of antimicrobial agents, 105924.

29. 12. Lu, R., Zhao, X., Li, J., Niu, P., Yang, B., Wu, H., ..\& Bi, Y. (2020). Genomic characterisation and epidemiology of 2019 novel coronavirus: implications for virus origins and receptor binding. The Lancet, 395(10224), 565-574.

30. 13. De Jong, M. D., Simmons, C. P., Thanh, T. T., Hien, V. M., Smith, G. J., Chau, T. N. B., ... \& Qui, P. T. (2006). Fatal outcome of human influenza A (H5N1) is associated with high viral load and hypercytokinemia. Nature medicine, 12(10), 1203-1207. 
31. 14. Wu, G. (2020). Important roles of dietary taurine, creatine, carnosine, anserine and 4hydroxyproline in human nutrition and health. Amino Acids, 1-32.

32. 15.Gabriele, M., \&Pucci, L. (2017). Diet bioactive compounds: Implications for oxidative stress and inflammation in the vascular system. Endocrine, Metabolic \& Immune DisordersDrug Targets (Formerly Current Drug Targets-Immune, Endocrine \& Metabolic Disorders), 17(4), 264-275.

33. 16. Wu, C., Chen, X., Cai, Y., Zhou, X., Xu, S., Huang, H., ...\& Song, J. (2020). Risk factors associated with acute respiratory distress syndrome and death in patients with coronavirus disease 2019 pneumonia in Wuhan, China. JAMA internal medicine.

34. 17. Zhou, F., Yu, T., Du, R., Fan, G., Liu, Y., Liu, Z., ...\& Guan, L. (2020). Clinical course and risk factors for mortality of adult inpatients with COVID-19 in Wuhan, China: a retrospective cohort study. The lancet.

35. Aristizábal B, González Á. Innate immune system. In: Anaya JM, Shoenfeld Y, RojasVillarraga A, et al., editors. Autoimmunity: From Bench to Bedside [Internet]. Bogota (Colombia): El Rosario University Press; 2013 Jul 18. Chapter 2.

36. Warrington, R., \&Silviu-Dan, F. (2011). Drug allergy. Allergy, Asthma \& Clinical Immunology, 7(1), S10.

37. Javier Chinen, $\mathrm{MD}, \mathrm{PhD}$, a Fred Finkelman, MD,b and William T. Shearer, MD, PhDc Houston, Tex, and Cincinnati, OhioAdvances in Asthma, Allergy, and Immunology Series 2006Advances in basic and clinical immunology

38. Gary R. Klimpel. Medical Microbiology. 4th edition Book.

39. Rouse, B. T., \&Sehrawat, S. (2010). Immunity and immunopathology to viruses: what decides the outcome? Nature Reviews Immunology, 10(7), 514-526.

40. Libbey, J. E., \& Fujinami, R. S. (2014). Adaptive immune response to viral infections in the central nervous system. In Handbook of clinical neurology (Vol. 123, pp. 225-247). Elsevier.

41. Mogensen, T. H., \&Paludan, S. R. (2001). Molecular pathways in virus-induced cytokine production. Microbiol. Mol. Biol. Rev., 65(1), 131-150.

42. Velazquez-Salinas, L., Verdugo-Rodriguez, A., Rodriguez, L. L., \&Borca, M. V. (2019). The role of interleukin 6 during viral infections. Frontiers in microbiology, 10, 1057.

43. Vinicius L. Ferreira and Helena H.L. Borba and Aline de F. Bonetti and Leticia P. Leonart and Roberto Pontarolo\}, (2019) chapter 4 Autoantibodies and Cytokines, Cytokines and 
Interferons: Types and Functions publisher-IntechOpen address-Rijeka. doi = $\{10.5772 /$ intechopen.74550\}

44. Waggoner, S. N., Reighard, S. D., Gyurova, I. E., Cranert, S. A., Mahl, S. E., Karmele, E. P., McNally, J. P., Moran, M. T., Brooks, T. R., Yaqoob, F., \&Rydyznski, C. E. (2016). Roles of natural killer cells in antiviral immunity. Current opinion in virology, 16, 15-23. https://doi.org/10.1016/j.coviro.2015.10.008

45. Alwarawrah, Y., Kiernan, K., \& MacIver, N. J. (2018). Changes in nutritional status impact immune cell metabolism and function. Frontiers in immunology, 9, 1055.

46. McKay, A. K., Heikura, I. A., Burke, L. M., Peeling, P., Pyne, D. B., van Swelm, R. P., ... \& Cox, G. R. (2020). Influence of Periodizing Dietary Carbohydrate on Iron Regulation and Immune Function in Elite Triathletes. International journal of sport nutrition and exercise metabolism, 30(1), 34-41.

47. McKay, A. K., Heikura, I. A., Burke, L. M., Peeling, P., Pyne, D. B., van Swelm, R. P., ... \& Cox, G. R. (2020). Influence of Periodizing Dietary Carbohydrate on Iron Regulation and Immune Function in Elite Triathletes. International journal of sport nutrition and exercise metabolism, 30(1), 34-41.

48. França, T. G. D., Ishikawa, L. L. W., Zorzella-Pezavento, S. F. G., Chiuso-Minicucci, F., da Cunha, M. L. R. S., \&Sartori, A. (2009). Impact of malnutrition on immunity and infection. Journal of Venomous Animals and Toxins including Tropical Diseases, 15(3), 374-390.

49. 23. Calder, P. C., Carr, A. C., Gombart, A. F., \&Eggersdorfer, M. (2020). Optimal nutritional status for a well-functioning immune system is an important factor to protect against viral infections. Nutrients, 12(4), 1181.

50. Shenkin A. (2006). Micronutrients in health and disease. Postgraduate medical journal, 82(971), 559-567. https://doi.org/10.1136/pgmj.2006.047670

51. Steinbrenner, H., Al-Quraishy, S., Dkhil, M. A., Wunderlich, F., \&Sies, H. (2015). Dietary selenium in adjuvant therapy of viral and bacterial infections. Advances in nutrition, 6(1), 7382.

52. Chandra, R. K. (1996). Nutrition, immunity and infection: from basic knowledge of dietary manipulation of immune responses to practical application of ameliorating suffering and improving survival. Proceedings of the National Academy of Sciences, 93(25), 14304-14307.

53. Suwannasom, N., Kao, I., Pruß, A., Georgieva, R., \& Bäumler, H. (2020). Riboflavin: The health benefits of a forgotten natural vitamin. International Journal of Molecular Sciences, 21(3), 950 . 
54. Kojima, Y., Yoshikawa, Y., Kajiwara, N., Anzai, H., \& Taniguchi, H. (2006). U.S. Patent Application No. 10/538,693.clinical nutrition, 55(7), 555-561.

55. Cunningham-Rundles, S., McNeeley, D. F., \& Moon, A. (2005). Mechanisms of nutrient modulation of the immune response. Journal of Allergy and Clinical Immunology, 115(6), 1119-1128.

56. Hemilä, H. (2017). Vitamin C and infections. Nutrients, 9(4), 339.

57. Jolliffe, D. A., Griffiths, C. J., \& Martineau, A. R. (2013). Vitamin D in the prevention of acute respiratory infection: systematic review of clinical studies. The Journal of steroid biochemistry and molecular biology, 136, 321-329.

58. Phillips, C. (2017). Lifestyle modulators of neuroplasticity: how physical activity, mental engagement, and diet promote cognitive health during aging. Neural plasticity, 2017.

59. Meydani, S. N., Han, S. N., \& Wu, D. (2005). Vitamin E and immune response in the aged: molecular mechanisms and clinical implications. Immunological reviews, 205(1), 269-284.

60. Li, Y., Yao, J., Han, C., Yang, J., Chaudhry, M. T., Wang, S., \& Yin, Y. (2016). Quercetin, inflammation and immunity. Nutrients, 8(3), 167.

61. Stephenson, A., Brotherwood, M., Robert, R., Durie, P., Verjee, Z., Chaparro, C., \&Tullis, E. (2005). Increased vitamin $\mathrm{A}$ and $\mathrm{E}$ levels in adult cystic fibrosis patients after lung transplantation. Transplantation, 79(5), 613-615.

62. West Jr, K. P., Howard, G. R., \& Sommer, A. (1989). Vitamin A and infection: public health implications. Annual review of nutrition, 9(1), 63-86.

63. Axelrod 1981 Axelrod A.E. (1981) Role of the B Vitamins in the Immune Response. In: Phillips M., Baetz A. (eds) Diet and Resistance to Disease. Springer, Boston, MA

64. Ifhar, L. S., \& Ben-Shachar, D. (2020). Heme metabolism, mitochondria, and complex I in neuropsychiatric disorders. In Neuroprotection in Autism, Schizophrenia and Alzheimer's disease (pp. 173-207). Academic Press.

65. Harsij, M., Kanani, H. G., \&Adineh, H. (2020). Effects of antioxidant supplementation (nanoselenium, vitamin $\mathrm{C}$ and $\mathrm{E}$ ) on growth performance, blood biochemistry, immune status and body composition of rainbow trout (Oncorhynchus mykiss) under sub-lethal ammonia exposure. Aquaculture, 734942.

66. Grant, W. B., Lahore, H., McDonnell, S. L., Baggerly, C. A., French, C. B., Aliano, J. L., \&Bhattoa, H. P. (2020). Evidence that Vitamin D Supplementation Could Reduce Risk of Influenza and COVID-19 Infections and Deaths. Nutrients, 12(4), 988. 
67. Drewnowski, A. (2010). The Nutrient-Rich Foods Index helps to identify healthy, affordable foods. The American journal of clinical nutrition, 91(4), 1095S-1101S.

68. Maggini, S., Pierre, A., \& Calder, P. C. (2018). Immune Function and Micronutrient Requirements Change over the Life Course. Nutrients, 10(10), 1531. https://doi.org/10.3390/nu10101531

69. Tam, M., Gomez, S., Gonzalez-Gross, M., \& Marcos, A. (2003). Possible roles of magnesium on the immune system. European journal of clinical nutrition, 57(10), 1193-1197.

70. Tiurin-Kuz'min, A. (2004). Role of Mg2+ in keeping up the nonspecific immune functions of human neutrophils in vitro during hyperbaric exposure. Aviakosmicheskaiaiekologicheskaiameditsina $=$ Aerospace and environmental medicine, $38(6), 48-51$.

71. Yao, Y., Ju, P., Liu, H., Wu, X., Niu, Z., Zhu, Y. .. \& Fang, Y. (2020). Ifenprodil rapidly ameliorates depressive-like behaviors, activates mTOR signaling and modulates proinflammatory cytokines in the hippocampus of CUMS rats. Psychopharmacology, 1-13.

72. Soyano A, Gómez M. Role of iron in immunity and its relation with infections Arch LatinoamNutr. 1999 Sep; 49(3 Suppl 2):40S-46S. Review. Spanish.

73. Jayaweera, J. A. A. S., Reyes, M., \& Joseph, A. (2019). Childhood iron deficiency anemia leads to recurrent respiratory tract infections and gastroenteritis. Scientific reports, 9(1), 1-8.

74. Hovdenak, N., \& Haram, K. (2012). Influence of mineral and vitamin supplements on pregnancy outcome. European Journal of Obstetrics \& Gynecology and Reproductive Biology, 164(2), 127-132.

75. Gombart, A. F., Pierre, A., \&Maggini, S. (2020). A Review of Micronutrients and the Immune System-Working in Harmony to Reduce the Risk of Infection. Nutrients, 12(1), 236.

76. Kewcharoenwong, C., Schuster, G. U., Wessells, K. R., Hinnouho, G. M., Balfour, M. A., Kounnavong, S.,\&Peerson, J. M. (2020). Daily Preventive Zinc Supplementation Decreases Lymphocyte and Eosinophil Concentrations in Rural Laotian Children from Communities with a High Prevalence of Zinc Deficiency: Results of a Randomized Controlled Trial.

77. Guillin, O. M., Vindry, C., Ohlmann, T., \&Chavatte, L. (2019). Selenium, Selenoproteins and Viral Infection. Nutrients, 11(9), 2101. https://doi.org/10.3390/nu11092101

78. Miyamoto, M. M., Slightom, J. L., \& Goodman, M. (1987). Phylogenetic relations of humans and African apes from DNA sequences in the psi eta-globin region. Science, 238(4825), 369373. 
79. Papanikolaou, Y., \&Fulgoni, V. L. (2017). Certain grain foods can be meaningful contributors to nutrient density in the diets of US children and adolescents: Data from the National Health and Nutrition Examination Survey, 2009-2012. Nutrients, 9(2), 160.

80. Orlov, A. P., Orlova, M. A., Trofimova, T. P., Kalmykov, S. N., \&Kuznetsov, D. A. (2018). The role of zinc and its compounds in leukemia. JBIC Journal of Biological Inorganic Chemistry, 23(3), 347-362.

81. Walsh, J.S., Bowles, S. and Evans, A.L. (2017) Vitamin D in obesity. Current Opinion in Endocrinology, Diabetes and Obesity, 24 (6). pp. 389-394. ISSN 1752-296X

82. Hill, A.; Wendt, S.; Benstoem, C.; Neubauer, C.; Meybohm, P.; Langlois, P.; Adhikari, N.K.; Heyland, D.K.; Stoppe, C. Vitamin C to Improve Organ Dysfunction in Cardiac Surgery Patients-Review and Pragmatic Approach. Nutrients 2018, 10, 974.

83. Ferreira, C. R., \&Gahl, W. A. (2017). Disorders of metal metabolism. Translational science of rare diseases, 2(3-4), 101-139.

84. Li, J., Yin, L., Wang, L., Li, J., Huang, P., Yang, H., \& Yin, Y. (2019). Effects of vitamin B6 on growth, diarrhea rate, intestinal morphology, function, and inflammatory factors expression in a high-protein diet fed to weaned piglets. Journal of animal science, 97(12), 4865-4874.

85. Jun Li, Lanmei Yin, Lei Wang, Jianzhong Li, Pengfei Huang, Huansheng Yang, Yulong Yin, Effects of vitamin B6 on growth, diarrhea rate, intestinal morphology, function, and inflammatory factors expression in a high-protein diet fed to weaned piglets, Journal of Animal Science, Volume 97, Issue 12, December 2019, Pages 4865-4874, https://doi.org/10.1093/jas/skz3382019

86. Molloy, E. J., \& Murphy, N. (2020). Vitamin D, Covid-19 and Children. Irish Medical Journal, 113(4), 64-64.

87. McCartney, D. M., \& Byrne, D. G. (2020). Optimisation of Vitamin D Status for Enhanced Immuno-protection Against Covid-19. Irish Medical Journal, 113(4), 58-58.

88. Carr, A. C. (2020). A new clinical trial to test high-dose vitamin C in patients with COVID19. Critical Care, 24(1), 1-2.

89. Liu, W., Zhang, L., Xu, H. J., Li, Y., Hu, C. M., Yang, J. Y., \& Sun, M. Y. (2018). The AntiInflammatory Effects of Vitamin D in Tumorigenesis. International journal of molecular sciences, 19(9), 2736. https://doi.org/10.3390/ijms19092736 
90. Calder, P. C., Carr, A. C., Gombart, A. F., \&Eggersdorfer, M. (2020). Optimal Nutritional Status for a Well-Functioning Immune System is an Important Factor to Protect against Viral Infections.

91. Calder, P. C. (2013). Omega-3 polyunsaturated fatty acids and inflammatory processes: nutrition or pharmacology?. British journal of clinical pharmacology, 75(3), 645-662.

92. Tam, M., Gomez, S., Gonzalez-Gross, M., \& Marcos, A. (2003). Possible roles of magnesium on the immune system. European journal of clinical nutrition, 57(10), 1193-1197.

93. Rayman, M. P. (2012). Selenium and human health. The Lancet, 379(9822), 1256-1268.

94. Chavasit, V., Pisaphab, R., Sungpuag, P., Jittinandana, S., \&Wasantwisut, E. (2002). Changes in $\beta$-Carotene and Vitamin A Contents of Vitamin A-rich Foods in Thailand during Preservation and Storage. Journal of food science, 67(1), 375-379.

95. Zhang, L., \& Liu, Y. (2020). Potential interventions for novel coronavirus in China: A systematic review. Journal of medical virology.

96. Berendsen, A. A., van Lieshout, L. E., van den Heuvel, E. G., Matthys, C., Péter, S., \& de Groot, L. C. (2016). Conventional foods, followed by dietary supplements and fortified foods, are the key sources of vitamin D, vitamin B6, and selenium intake in Dutch participants of the NU-AGE study. Nutrition Research, 36(10), 1171-1181.

97. Fonthana, E. T. (2012). Vitamin C, vitamin C-rich foods, and cancer: epidemiologic studies. Natural antioxidants in human health and disease, 157.

98. Birgisdottir, B. E., Brantsæter, A. L., Kvalem, H. E., Knutsen, H. K., Haugen, M., Alexander, J., .. \& Meltzer, H. M. (2012). Fish liver and seagull eggs, vitamin D-rich foods with a shadow: Results from the Norwegian Fish and Game Study. Molecular nutrition \& food research, 56(3), 388-398.

99. McGavin, J. K., Mann, J. I., Skeaff, C. M., \& Chisholm, A. (2001). Comparison of a vitamin E-rich diet and supplemental vitamin E on measures of vitamin E status and lipoprotein profile. European Journal of (incomplete)

100. Nonnecke, B. J., McGill, J. L., Ridpath, J. F., Sacco, R. E., Lippolis, J. D., \& Reinhardt, T. A. (2014). The acute-phase response elicited by experimental bovine diarrhea virus (BVDV) infection is associated with decreased vitamin D and E status of vitamin-replete pre ruminant calves. Journal of dairy science, 97(9), 5566-5579.

101. Sebastiani, G., Saeed, S., Lebouche, B., de Pokomandy, A., Szabo, J., Haraoui, L. P., \& Klein, M. (2020). Vitamin $\mathrm{E}$ is an effective treatment for nonalcoholic steatohepatitis in HIV mono-infected patients. Aids, 34(2), 237-244. 
102. Drusch, S., \&Mannino, S. (2009). Patent-based review on industrial approaches for the microencapsulation of oils rich in polyunsaturated fatty acids. Trends in Food Science \& Technology, 20(6-7), 237-244.

103. Grzebisz, W. (2011). Magnesium-food and human health. Journal of Elementology, 16(2).

104. Lucca, P., Hurrell, R., \&Potrykus, I. (2002). Fighting iron deficiency anemia with iron-rich rice. Journal of the American College of Nutrition, 21(sup3), 184S-190S.

105. Hu, Y., H McIntosh, G., \& P Young, G. (2012). Selenium-rich foods: a promising approach to colorectal cancer prevention. Current pharmaceutical biotechnology, 13(1), 165-172.

106. Mlambo, V., \&Mapiye, C. (2015). Towards household food and nutrition security in semiarid areas: What role for condensed tannin-rich ruminant feedstuffs. Food Research International, 76, 953-961.

107. Li, X., Duan, S., Chu, C., Xu, J., Zeng, G., Lam, A. K. Y., \&Gu, H. (2013). Melaleuca alternifolia concentrate inhibits in vitro entry of influenza virus into host cells. Molecules, 18(8), 9550-9566.

108. Wu, S., Patel, K. B., Booth, L. J., Metcalf, J. P., Lin, H. K., \& Wu, W. (2010). Protective essential oil attenuates influenza virus infection: an in vitro study in MDCK cells. BMC complementary and alternative medicine, 10, 69. https://doi.org/10.1186/1472-6882-10-69.

109. Henson, C. C., Burden, S., Davidson, S. E., \& Lal, S. (2013). Nutritional interventions for reducing gastrointestinal toxicity in adults undergoing radical pelvic radiotherapy. Cochrane database of systematic reviews, (11).

110. Simon, A. K., Hollander, G. A., \& McMichael, A. (2015). Evolution of the immune system in humans from infancy to old age. Proceedings. Biological sciences, 282(1821), 20143085. https://doi.org/10.1098/rspb.2014.3085

111. Barker, M., Dombrowski, S. U., Colbourn, T., Fall, C. H., Kriznik, N. M., Lawrence, W. T., \&Sniehotta, F. F. (2018). Intervention strategies to improve nutrition and health behaviours before conception. The Lancet, 391(10132), 1853-1864.

112. Robinson, S. M. (2018). Improving nutrition to support healthy ageing: what are the opportunities for intervention? Proceedings of the Nutrition Society, 77(3), 257-264.

113. Vasto, S., Malavolta, M., \&Pawelec, G. (2006). Age and immunity. Immun. Aging, 3(2).

114. Liu, Q., Zhou, Y. \& Yang, Z. The cytokine storm of severe influenza and development of immunomodulatory therapy. Cell MolImmunol 13, 3-10 (2016). https://doi.org/10.1038/cmi.2015.74

115. Erol, A. (2020). High-dose intravenous vitamin C treatment for COVID-19. 
116. Daneshkhah, A., Eshein, A., Subramanian, H., Roy, H. K., \& Backman, V. (2020). The Role of Vitamin D in Suppressing Cytokine Storm in COVID-19 Patients and Associated Mortality. medRxiv.

117. Alipio, M. (2020). Vitamin D Supplementation Could Possibly Improve Clinical Outcomes of Patients Infected with Coronavirus-2019 (COVID-19). Available at SSRN 3571484.

118. Raharusun, P. (2020). Patterns of COVID-19 Mortality and Vitamin D: An Indonesian Study. Available at SSRN 3585561.

119. https://about.unimelb.edu.au/newsroom/news/2020/april/world-first-trial-to-test-benefit-ofintravenous-zinc-in-covid-19-fight

120. Tan, C. W., Ho, L. P., Kalimuddin, S., Cherng, B. P. Z., Teh, Y. E., Thien, S. Y., ... \& Sultana, R. (2020). A cohort study to evaluate the effect of combination Vitamin D, Magnesium and Vitamin B12 (DMB) on progression to severe outcome in older COVID-19 patients. medRxiv.

121. Horowitz, R. I., Freeman, P. R., \&Bruzzese, J. (2020). Efficacy of glutathione therapy in relieving dyspnea associated with COVID-19 pneumonia: A report of 2 cases. Respiratory medicine case reports, 101063.upplements.

122. Abdel-Mottaleb, M. S., \& Abdel-Mottaleb, Y. (2020). In search for effective and safe drugs against SARS-CoV-2: Part III] The electronic factors of Remdesivir and the naturally extracted Aspirochlorine drugs.

123. Carr, A. C. (2020). A new clinical trial to test high-dose vitamin C in patients with COVID19. Critical Care, 24(1), 1-2.

124. Alipio, M. (2020). Vitamin D Supplementation Could Possibly Improve Clinical Outcomes of Patients Infected with Coronavirus-2019 (COVID-19). Available at SSRN 3571484.

125. Grant, W. B., Lahore, H., McDonnell, S. L., Baggerly, C. A., French, C. B., Aliano, J. L., \&Bhattoa, H. P. (2020). Evidence that vitamin D supplementation could reduce risk of influenza and COVID-19 infections and deaths. Nutrients, 12(4), 988.

126. Drewnowski, A. (2010). The Nutrient Rich Foods Index helps to identify healthy, affordable foods. The American journal of clinical nutrition, 91(4), 1095S-1101S.

127. Calder, P. C., Carr, A. C., Gombart, A. F., \&Eggersdorfer, M. (2020). Optimal Nutritional Status for a Well-Functioning Immune System is an Important Factor to Protect Against Viral Infections. 
128. Panigada, M., Bottino, N., Tagliabue, P., Grasselli, G., Novembrino, C., Chantarangkul, V., ... \& Tripodi, A. (2020). Hypercoagulability of COVID-19 patients in intensive care unit. A report of thromboelastography findings and other parameters of hemostasis. Journal of Thrombosis and Haemostasis.

129. Mast, A. E., Blinder, M. A., \& Dietzen, D. J. (2008). Reticulocyte hemoglobin content. American journal of hematology, 83(4), 307-310.

130. Harch, P. G. (2020). Hyperbaric oxygen treatment of novel coronavirus (COVID-19) respiratory failure. Medical Gas Research, 10(2), 61.

131. Ifhar, L. S., \& Ben-Shachar, D. (2020). Heme metabolism, mitochondria, and complex I in neuropsychiatric disorders. In Neuroprotection in Autism, Schizophrenia and Alzheimer's Disease (pp. 173-207). Academic Press.

132. Steinbrenner, H., Al-Quraishy, S., Dkhil, M. A., Wunderlich, F., \& Sies, H. (2015). Dietary selenium in adjuvant therapy of viral and bacterial infections. Advances in nutrition, 6(1), 7382.

133. Skalny, A. V., Rink, L., Ajsuvakova, O. P., Aschner, M., Gritsenko, V. A., Alekseenko, S. I., ... \& Tsatsakis, A. (2020). Zinc and respiratory tract infections: Perspectives for COVID19. International Journal of Molecular Medicine, 46(1), 17-26.

134. Liu, W., \& Li, H. (2020). COVID-19: attacks the 1-beta chain of hemoglobin and captures the porphyrin to inhibit human heme metabolism. Preprint revised on, 10 (04).

135. Jayaweera, J. A. A. S., Reyes, M., \& Joseph, A. (2019). Childhood iron deficiency anemia leads to recurrent respiratory tract infections and gastroenteritis. Scientific reports, 9(1), 1-8.

136. Yuan, M., Yin, W., Tao, Z., Tan, W., \& Hu, Y. (2020). Association of radiologic findings with mortality of patients infected with 2019 novel coronavirus in Wuhan, China. PloS one, 15(3), e0230548.

137. Ayensu, J., Annan, R., Lutterodt, H., Edusei, A., \& Peng, L. S. (2020). Prevalence of anaemia and low intake of dietary nutrients in pregnant women living in rural and urban areas in the Ashanti region of Ghana. Plos one, 15(1), e0226026.

138. Ogawa, C., Tsuchiya, K., \& Maeda, K. (2020). Reticulocyte hemoglobin content. ClinicaChimicaActa.

139. Al-Salem, A. H. (2020). Nutrition for Infants and Children. In Atlas of Pediatric Surgery (pp. 7-9). Springer, Cham. 
140. Suchdev, P. S., \&Trehan, I. (2020). Optimizing iron supplementation for children with severe malaria. The American Journal of Clinical Nutrition.

141. Swerdloff, R. S., \& Odell, W. D. (1975). Hormonal mechanisms in the onset of puberty. Postgraduate medical journal, 51(594), 200-208. https://doi.org/10.1136/pgmj.51.594.200

142. Channappanavar, R., Fett, C., Mack, M., Ten Eyck, P. P., Meyerholz, D. K., \& Perlman, S. (2017). Sex-Based Differences in Susceptibility to Severe Acute Respiratory Syndrome Coronavirus Infection. Journal of immunology (Baltimore, Md.: 1950), 198(10), 4046-4053. https://doi.org/10.4049/jimmunol.1601896

143. Scaglioni, S., De Cosmi, V., Ciappolino, V., Parazzini, F., Brambilla, P., \&Agostoni, C. (2018). Factors Influencing Children's Eating Behaviours. Nutrients, 10(6), 706. https://doi.org/10.3390/nu10060706

144. Goudet SM, Bogin BA, Madise NJ, Griffiths PL. Nutritional interventions for preventing stunting in children (birth to 59 months) living in urban slums in low- and middle-income countries (LMIC). Cochrane Database of Systematic Reviews 2019, Issue 6. Art. No.: CD011695. DOI: 10.1002/14651858.CD011695.pub2.

145. DemoGothié, J. D., Vancamp, P., Demeneix, B., \&Remaud, S. (2020). Thyroid hormone regulation of neural stem cell fate: From development to aging. ActaPhysiologica, 228(1), e13316.graphic Health Survey 2016. PloS one, 15(3), e0218840. Bista, B., Dhungana, R. R., Chalise, B., \& Pandey, A. R. (2020). Prevalence and determinants of non-communicable diseases risk factors among reproductive-aged women of Nepal: Results from Nepal

146. Bista, B., Dhungana, R. R., Chalise, B., \& Pandey, A. R. (2020). Prevalence and determinants of non-communicable diseases risk factors among reproductive-aged women of Nepal: Results from Nepal

147. Panarese, A., Pesce, F., Porcelli, P., Riezzo, G., Iacovazzi, P. A., Leone, C. M., De Carne, M., Rinaldi, C. M., \&Shahini, E. (2019). Chronic functional constipation is strongly linked to vitamin D deficiency. World journal of gastroenterology, 25(14), 1729-1740. https://doi.org/10.3748/wjg.v25.i14.1729 (Panarese et al., 2019)

148. Kilaru, S., Pereira, P., Chandra, B. S., Hattur, B., \&Chalasani, S. H. (2020). A study of magnitude of zinc deficiency and effectiveness of zinc supplementation among elderly with zinc deficiency. International Journal of Health \& Allied Sciences, 9(1), 21.

149. TeVelthuis, A. J., van den Worm, S. H., Sims, A. C., Baric, R. S., Snijder, E. J., \& van Hemert, M. J. (2010). Zn2+ inhibits coronavirus and arterivirus RNA polymerase activity in 
vitro and zinc ionophores block the replication of these viruses in cell culture. PLoS pathogens, 6(11).

150. Harch, P. G. (2020). Hyperbaric oxygen treatment of novel coronavirus (COVID-19) respiratory failure

151. Leu, G. Z., Lin, T. Y., \& Hsu, J. T. (2004). Anti-HCV activities of selective polyunsaturated fatty acids. Biochemical and biophysical research communications, 318(1), 275-280.

152. Yang, J., Wang, H. P., Zhou, L., \& Xu, C. F. (2012). Effect of dietary fiber on constipation: a meta-analysis. World journal of gastroenterology, 18(48), 7378-7383. https://doi.org/10.3748/wjg.v18.i48.7378

153. Jędrusek-Golińska, A., Górecka, D., Buchowski, M., Wieczorowska-Tobis, K., Gramza-Michałowska, A., \&Szymandera-Buszka, K. (2020). Recent progress in the use of functional foods for older adults: A narrative review. Comprehensive Reviews in Food Science and Food Safety, 19(2), 835-856.

154. Parker, M.E., Zobrist, S., Lutterodt, H.E. et al. Evaluating the nutritional content of an insectfortified food for the child complementary diet in Ghana. BMC Nutr 6, 7 (2020). https://doi.org/10.1186/s40795-020-0331-6

155. Ray, B., Hutterer, C., Bandyopadhyay, S. S., Ghosh, K., Chatterjee, U. R., Ray, S., \&Marschall, M. (2013). Chemically engineered sulfated glucans from rice bran exert strong antiviral activity at the stage of viral entry. Journal of natural products, 76(12), 2180-2188.

156. Azzolino, D., Arosio, B., Marzetti, E., Calvani, R., \&Cesari, M. (2020). Nutritional Status as a Mediator of Fatigue and Its Underlying Mechanisms in Older People. Nutrients, 12(2), 444.

157. Torrubia, B., Martín-Fernández, M., Rubert, M., Gómez-Chinchón, M., Sosa, M., Díez-Pérez, A., \& de la Piedra, C. (2020). Effects of calcium and vitamin d supplementation on bone quality in an ovariectomized rat model. Journal of Surgery.

158. Schilling, R. (2019). Coping with COVID-19 Coronavirus.

159. Vingilis, E., Brown, U., \&Hennen, B. (1999). Common colds. Reported patterns of self-care and health care use. Canadian Family Physician, 45, 2644.

160. Ueda, K., Kawabata, R., Irie, T., Nakai, Y., Tohya, Y., \&Sakaguchi, T. (2013). Inactivation of pathogenic viruses by plant-derived tannins: strong effects of extracts from persimmon (Diospyros kaki) on a broad range of viruses. PloS one, 8(1).

161. Chung KT, Wong TY, Wei CI, Huang YW, Lin Y. Tannins and human health: a review. Crit Rev Food SciNutr. 1998;38(6):421-464. doi:10.1080/10408699891274273 
162. Zhang, L., \& Liu, Y. (2020). Potential interventions for novel coronavirus in China: A systematic review. Journal of medical virology, 92(5), 479-490.

Table 1: Common health issues and immunity involved health complications associated with nutrient deficiencies

\begin{tabular}{|c|c|c|}
\hline $\begin{array}{l}\text { Nutrients } \\
\text { deficiency }\end{array}$ & $\begin{array}{c}\text { Consequences } \\
\text { (Immunity involved health issues) }\end{array}$ & Ref \\
\hline \multirow[b]{2}{*}{$\begin{array}{l}\text { Vitamin A } \\
\text { (antioxidant) }\end{array}$} & \multirow{2}{*}{$\begin{array}{l}\text { I) Impaired of innate immunity (frequent throat and chest } \\
\text { infections), hematopoiesis and typical ocular effects } \\
\text { II) Stunted growth in children } \\
\text { III) Increased infertility and trouble conceiving among } \\
\text { women }\end{array}$} & [59] \\
\hline & & {$[60]$} \\
\hline Vitamin B1 & $\begin{array}{l}\text { I)Shortness of breath } \\
\text { II)Reduced reflexes and muscle weakness }\end{array}$ & {$[61]$} \\
\hline $\begin{array}{l}\text { Vitamin B6 } \\
\text { (cofactor of } \\
\text { hemoglobin } \\
\text { synthesis) }\end{array}$ & $\begin{array}{l}\text { I) Hampered the hemoglobin synthesis that leads to } \\
\text { decrease in oxygen level in the human body }\end{array}$ & {$[62]$} \\
\hline Vitamin B2 & $\begin{array}{l}\text { I)Normochromic-normocytic anemia } \\
\text { II)Increased oxidative stress, inflammation and cell } \\
\text { proliferation }\end{array}$ & {$[63]$} \\
\hline $\begin{array}{c}\text { Vitamin C } \\
\text { (Antioxidant) }\end{array}$ & $\begin{array}{l}\text { I)Poor immunity } \\
\text { II) Pneumonia } \\
\text { III) Impaired bone growth in children }\end{array}$ & {$[64]$} \\
\hline Vitamin D & $\begin{array}{l}\text { I) Increased replication rate of viruses } \\
\text { II)Declined concentration of pro-inflammatory substances } \\
\text { (cytokines) }\end{array}$ & {$[65]$} \\
\hline $\begin{array}{l}\text { Vitamin E } \\
\text { (Antioxidant) }\end{array}$ & $\begin{array}{l}\text { I)Increased inflammation rate } \\
\text { II) Retard physical and mental growth in children }\end{array}$ & $\begin{array}{l}{[66]} \\
{[67]}\end{array}$ \\
\hline
\end{tabular}




\begin{tabular}{|c|l|c|}
\hline $\begin{array}{c}\text { Magnesium } \\
\text { (Electrolyte) }\end{array}$ & $\begin{array}{l}\text { II) Impaired innate and acquired immune responses as well } \\
\text { as immunoglobulin synthesis }\end{array}$ & $\begin{array}{c}\text { [68][69] } \\
{[69]}\end{array}$ \\
\hline Iron & $\begin{array}{l}\text { II) Impaired immune cells proliferation and maturation and } \\
\text { a particular response to infection } \\
\text { II) Cognitive and behavioral problems in children } \\
\text { III)Recurrent acute respiratory tract infections }\end{array}$ & [70][71][72] \\
\hline Zinc & $\begin{array}{l}\text { I) Impaired the outgrowth and activation of T lymphocytes, } \\
\text { B lymphocytes, antibody production (specifically } \\
\text { Immunoglobulin G) and decreased eosinophils } \\
\text { concentration, } \\
\text { II) Retarded fetus growth by causing the recurrent abortion } \\
\text { in pregnant women }\end{array}$ & [73][74] \\
\hline Selenium & $\begin{array}{l}\text { I) Induced the mutation of innocuous strains of RNA } \\
\text { viruses (Influenza virus, Coxsackie viruses) to heavily } \\
\text { pathogenic strains } \\
\text { II) Accountable for recurrent abortion in pregnant women }\end{array}$ & \\
\hline
\end{tabular}

Table 2: General supportive and key food items to stimulate human immune system

\begin{tabular}{|c|c|c|c|c|c|}
\hline \multirow{2}{*}{$\begin{array}{c}\text { Nutrition } \\
\text { Intervention } \\
\quad \mathbf{S}\end{array}$} & \multirow{2}{*}{$\begin{array}{l}\text { Susceptible } \\
\text { viruses }\end{array}$} & \multicolumn{3}{|c|}{ Major Food groups } & \multirow[b]{2}{*}{ Ref. } \\
\hline & & Plant origin & Animal origin & $\begin{array}{l}\text { Others (Processed } \\
\text { food and nutrient } \\
\text { supplementation) }\end{array}$ & \\
\hline $\begin{array}{l}\text { Fat-soluble } \\
\text { Vitamin A }\end{array}$ & $\begin{array}{c}\text { Measles } \\
\text { virus, Human } \\
\text { Immunodefici } \\
\text { ency Virus } \\
\text { (HIV), Avian } \\
\text { Coronavirus }\end{array}$ & $\begin{array}{c}\text { Orange and } \\
\text { yellow } \\
\text { vegetables, fruit } \\
\text { s, broccoli, most } \\
\text { dark green } \\
\text { vegetables, } \\
\text { spinach }\end{array}$ & $\begin{array}{l}\text { Eggs, cod liver } \\
\text { oil, beef liver }\end{array}$ & Fortified skim milk & {$[92]$} \\
\hline $\begin{array}{l}\text { Water- } \\
\text { soluble } \\
\text { Vitamin B } \\
\text { complexes }\end{array}$ & $\begin{array}{l}\text { MERS-CoV; } \\
\text { Ventilator-ind } \\
\text { uced Lung } \\
\text { Injury }\end{array}$ & $\begin{array}{c}\text { Brown rice, } \\
\text { legumes, } \\
\text { sunflower seeds } \\
\text { and nuts, fruits } \\
\text { (bananas, citrus } \\
\text { fruits), dark } \\
\text { leafy } \\
\text { vegetables }\end{array}$ & $\begin{array}{c}\text { Red meat, } \\
\text { poultry, fish, } \\
\text { eggs, salmon, } \\
\text { liver and other } \\
\text { organ } \\
\text { meats,milk, } \\
\text { cheese, oysters, } \\
\text { mussels, pork }\end{array}$ & $\begin{array}{l}\text { Cheese, yogurt, } \\
\text { nutritional and } \\
\text { brewer's yeasts, } \\
\text { fortified cereal }\end{array}$ & {$[93]$} \\
\hline
\end{tabular}




\begin{tabular}{|c|c|c|c|c|c|}
\hline Vitamin B6 & HIV & $\begin{array}{l}\text { Bread, whole } \\
\text { grain cereals } \\
\text { (brown rice, oat } \\
\text { meal), } \\
\text { vegetables, } \\
\text { Soybean, } \\
\text { potatoes, } \\
\text { banana, } \\
\text { spinach, seeds, } \\
\text { carrot }\end{array}$ & $\begin{array}{l}\text { Pork, fish, } \\
\text { poultry } \\
\text { (Chicken, } \\
\text { turkey), eggs, } \\
\text { milk, beef } \\
\text { liver, beef }\end{array}$ & $\begin{array}{l}\text { Vitamin B6 can be } \\
\text { used as dietary } \\
\text { supplement }\end{array}$ & [94] \\
\hline Vitamin C & $\begin{array}{l}\text { Avian } \\
\text { Coronavirus; } \\
\text { Lower } \\
\text { respiratory } \\
\text { tract } \\
\text { infections }\end{array}$ & $\begin{array}{l}\text { Citrus fruits, } \\
\text { broccoli, } \\
\text { cauliflower, } \\
\text { sweet potato, } \\
\text { strawberries, } \\
\text { tomatoes, } \\
\text { papaya }\end{array}$ & $\begin{array}{l}\text { Beef liver, } \\
\text { oysters, pork } \\
\text { liver, eggs }\end{array}$ & $\begin{array}{l}\text { Vitamin } \mathrm{C} \text { tablets } \\
\text { can be taken as a } \\
\text { supplementation }\end{array}$ & [95] \\
\hline Vitamin D & $\begin{array}{c}\text { Bovine } \\
\text { Coronavirus }\end{array}$ & $\begin{array}{l}\text { seaweeds, oat, } \\
\text { soy milk, } \\
\text { cereal, }\end{array}$ & $\begin{array}{l}\text { Marine fish, } \\
\text { beef liver, } \\
\text { cheese, egg } \\
\text { yolk, milk, } \\
\text { shrimp, } \\
\text { mushrooms }\end{array}$ & $\begin{array}{l}\text { Cheese, fortified } \\
\text { soy milk, fortified } \\
\text { cereal, Vitamin D } \\
\text { tablets can be } \\
\text { taken as a } \\
\text { supplementation }\end{array}$ & [96] \\
\hline Vitamin E & $\begin{array}{l}\text { Coxsackie } \\
\text { Virus, Bovine } \\
\text { Coronavirus, } \\
\text { HIV virus }\end{array}$ & $\begin{array}{l}\text { Vegetable oils, } \\
\text { nuts, seeds, } \\
\text { green leafy } \\
\text { vegetables }\end{array}$ & $\begin{array}{c}\text { Marine fish, } \\
\text { octopus, goose } \\
\text { meat }\end{array}$ & $\begin{array}{l}\text { Vitamin E fortified } \\
\text { oil, Vitamin E } \\
\text { capsule can be } \\
\text { taken as a } \\
\text { supplement }\end{array}$ & $\begin{array}{c}{[97][98]} \\
{[99]}\end{array}$ \\
\hline $\begin{array}{c}\text { Omega-3 } \\
\text { polyunsaturat } \\
\text { ed fatty acids } \\
\text { (PUFA) }\end{array}$ & $\begin{array}{c}\text { Influenza } \\
\text { virus, Human } \\
\text { Immunodefici } \\
\text { ency virus }\end{array}$ & $\begin{array}{l}\text { walnuts, canola } \\
\text { oil, spinach, } \\
\text { soybeans }\end{array}$ & $\begin{array}{l}\text { Marine fish, } \\
\text { shrimp, } \\
\text { oysters, }\end{array}$ & $\begin{array}{l}\text { Omega-3 fatty } \\
\text { acids can be used } \\
\text { as supplements }\end{array}$ & {$[100]$} \\
\hline Magnesium & & $\begin{array}{c}\text { Green leafy } \\
\text { vegetables, } \\
\text { fruits ( banana, } \\
\text { avocado), nuts, } \\
\text { seeds, legumes, } \\
\text { peas, spinach, } \\
\text { oatmeal }\end{array}$ & $\begin{array}{c}\text { seafood } \\
\text { (Salmon, } \\
\text { mackerel, } \\
\text { tuna), shrimp, } \\
\text { egg, milk, } \\
\text { beef, chicken, }\end{array}$ & Magnesium pills & {$[101]$} \\
\hline Iron & $\begin{array}{c}\text { Viral } \\
\text { mutations }\end{array}$ & $\begin{array}{c}\text { Legumes, } \\
\text { pumpkin seeds, } \\
\text { nuts, oats, } \\
\text { brown rice, } \\
\text { spinach, beans, } \\
\text { potatoes }\end{array}$ & $\begin{array}{l}\text { organ meats, } \\
\text { beef spleen, } \\
\text { pork liver, } \\
\text { clams, egg } \\
\text { yolk, shrimp }\end{array}$ & $\begin{array}{c}\text { Dark chocolate, } \\
\text { meanwhile Iron the } \\
\text { tablet can be taken } \\
\text { as a } \\
\text { supplementation }\end{array}$ & [102] \\
\hline Zinc & $\begin{array}{c}\text { Measles } \\
\text { virus, } \\
\text { SARS-CoV }\end{array}$ & $\begin{array}{c}\text { nuts, sesame } \\
\text { seeds, pumpkin } \\
\text { seeds, soybeans }\end{array}$ & $\begin{array}{l}\text { Meat, shellfish, } \\
\text { dairy products, } \\
\text { eggs, poultry }\end{array}$ & $\begin{array}{c}\text { Cheese, dark } \\
\text { chocolate, cocoa } \\
\text { powder }\end{array}$ & [52] \\
\hline
\end{tabular}




\begin{tabular}{|c|c|c|c|c|c|}
\hline & & whole grains & & & \\
\hline Selenium & $\begin{array}{c}\text { Influenza } \\
\text { Virus, Avian } \\
\text { Coronavirus; } \\
\text { Viral } \\
\text { mutations } \\
\end{array}$ & $\begin{array}{c}\text { Almonds, } \\
\text { pumpkin seeds, } \\
\text { sunflower } \\
\text { seeds, whole } \\
\text { wheat bread }\end{array}$ & $\begin{array}{c}\text { Fish, eggs } \\
\text { pork, beef, } \\
\text { chicken, turkey }\end{array}$ & & [103] \\
\hline Tannins & $\begin{array}{l}\text { Influenza } \\
\text { Virus }\end{array}$ & $\begin{array}{c}\text { Tea (Green } \\
\text { Tea, Oolong } \\
\text { Tea, Black Tea, } \\
\text { Puer Tea), } \\
\text { berries, walnuts }\end{array}$ & $\begin{array}{l}\text { Not available } \\
\text { in animals }\end{array}$ & wine, chocolates & [104] \\
\hline Essential oils & $\begin{array}{l}\text { reducing flu } \\
\text { virus (RNA } \\
\text { virus) activity } \\
\text { in vitro }\end{array}$ & $\begin{array}{l}\text { carrot seed, } \\
\text { cinnamon bark, } \\
\text { clove bud, } \\
\text { sweet orange, } \\
\text { eucalyptus, } \\
\text { rosemary, and } \\
\text { orange, lemon }\end{array}$ & $\begin{array}{l}\text { Not available } \\
\text { in animals }\end{array}$ & $\begin{array}{c}\text { Essential oils are } \\
\text { available as } \\
\text { supplements }\end{array}$ & $\begin{array}{l}{[105]} \\
{[106]}\end{array}$ \\
\hline
\end{tabular}

Table 3: Current status of nutritional intervention strategies for COVID-19 patients

\begin{tabular}{|c|c|c|c|c|c|}
\hline $\begin{array}{l}\text { Nutritional } \\
\text { Intervention }\end{array}$ & $\begin{array}{l}\text { Nutrient } \\
\text { Type }\end{array}$ & $\begin{array}{l}\text { Applied } \\
\text { Nutrients }\end{array}$ & $\begin{array}{l}\text { Mode of Actions } \\
\text { against COVID- } \\
19\end{array}$ & $\begin{array}{l}\text { Referred } \\
\text { Countries }\end{array}$ & Ref. \\
\hline $\begin{array}{c}\text { Dietary } \\
\text { approach and } \\
\text { supplementation }\end{array}$ & Micronutrient & Vitamin C & $\begin{array}{l}\text { 1)Inhibit cytokine } \\
\text { storm through } \\
\text { reducing } \\
\text { inflammation rate } \\
\text { 2) Reduce } \\
\text { respiratory tract } \\
\text { infection }\end{array}$ & $\begin{array}{l}\text { China, Italy, } \\
\text { USA, Iran, } \\
\text { Bangladesh }\end{array}$ & $\begin{array}{l}{[112]} \\
{[113]}\end{array}$ \\
\hline $\begin{array}{c}\text { Dietary } \\
\text { approach and } \\
\text { supplementation }\end{array}$ & Micronutrient & Vitamin D & $\begin{array}{l}\text { 1)Vitamin D } \\
\text { tablets can be } \\
\text { taken to reduce } \\
\text { mortality rate } \\
\text { 2)Suppress } \\
\text { cytokine storm in } \\
\text { human body }\end{array}$ & $\begin{array}{c}\text { China, } \\
\text { France, Italy, } \\
\text { USA, } \\
\text { Germany, } \\
\text { Iran, South } \\
\text { Korea, } \\
\text { Philippine, } \\
\text { Indonesia }\end{array}$ & $\begin{array}{l}{[114]} \\
{[115]} \\
{[116]}\end{array}$ \\
\hline $\begin{array}{c}\text { Dietary } \\
\text { approach and }\end{array}$ & Micronutrient & Zinc & $\begin{array}{l}\text { Hypothesized to } \\
\text { treat COVID-19 } \\
\text { patients with it }\end{array}$ & $\begin{array}{l}\text { University of } \\
\text { Melbourn } \\
\text { proposed for }\end{array}$ & [117] \\
\hline
\end{tabular}




\begin{tabular}{|c|c|c|c|c|c|}
\hline supplementation & & & $\begin{array}{l}\text { due to its antiviral } \\
\text { activities and } \\
\text { modulation of } \\
\text { immune response }\end{array}$ & $\begin{array}{l}\text { the world } \\
\text { first trial }\end{array}$ & \\
\hline $\begin{array}{c}\text { Combined } \\
\text { supplementation }\end{array}$ & Micronutrients & $\begin{array}{l}\text { Magnesiu } \\
\text { m, } \\
\text { Vitamin } \\
\text { B12, } \\
\text { Vitamin D }\end{array}$ & $\begin{array}{l}\text { Reduce patients' } \\
\text { demands for } \\
\text { oxygen support } \\
\text { and intensive care } \\
\text { support }\end{array}$ & China & [118] \\
\hline $\begin{array}{c}\text { Oral } \\
\text { Supplementation }\end{array}$ & $\begin{array}{c}\text { Macronutrient } \\
\text { (Protein) }\end{array}$ & $\begin{array}{l}\text { High dose } \\
\text { oral and/or } \\
\text { IV } \\
\text { Glutathion } \\
\text { e }\end{array}$ & $\begin{array}{l}\text { Reduces } \\
\text { respiratory } \\
\text { symptoms }\end{array}$ & $\begin{array}{c}\text { New York, } \\
\text { USA }\end{array}$ & [119] \\
\hline $\begin{array}{c}\text { Food } \\
\text { supplementation }\end{array}$ & Micronutrients & $\begin{array}{l}\text { Copper, } \\
\text { Iodine, } \\
\text { Selenium, } \\
\text { Zinc }\end{array}$ & $\begin{array}{c}\text { Immune } \\
\text { enhancers } \\
\text { towards SARS } \\
\text { CoV } 2\end{array}$ & Egypt & [120] \\
\hline
\end{tabular}

Table 4: Nutrient recommendations of COVID-19 patients based on different age groups and physiological conditions

\begin{tabular}{|c|c|c|c|c|}
\hline Target groups & Complications & Recommendations & Health Benefits & Ref. \\
\hline $\begin{array}{l}\text { Pregnant and } \\
\text { lactating women }\end{array}$ & $\begin{array}{c}\text { Iron, zinc, } \\
\text { calcium, vitamin } \\
\text { A, vitamin D, } \\
\text { and folic acid } \\
\text { deficiency }\end{array}$ & $\begin{array}{l}\text { Protein, } \mathrm{Zn}, \mathrm{Ca} \text {, and } \\
\text { folate-rich food. } \\
\text { Supplementation is } \\
\text { prohibited for infants. }\end{array}$ & $\begin{array}{l}\text { Reduces } \\
\text { infection in child } \\
\text { by increasing the } \\
\text { immune } \\
\text { response }\end{array}$ & $\begin{array}{l}{[135][136]} \\
{[137][138]}\end{array}$ \\
\hline Puberty & $\begin{array}{c}\text { During } \\
\text { fetusdevelopme } \\
\text { nt enormous } \\
\text { hormonal } \\
\text { changes occur } \\
\text { which are } \\
\text { associated with } \\
\text { sexual } \\
\text { maturation }\end{array}$ & $\begin{array}{l}\text { Nutritional balance is } \\
\text { linked to hormonal } \\
\text { balance and can be } \\
\text { achieved through } \\
\text { improved family food } \\
\text { behaviors }\end{array}$ & $\begin{array}{l}\text { Introduces long } \\
\text { term immunity }\end{array}$ & $\begin{array}{l}{[139][140]} \\
{[141][142]}\end{array}$ \\
\hline Adults & $\begin{array}{l}\text { prone to viral } \\
\text { infections due to }\end{array}$ & Vitamin D & $\begin{array}{c}\text { Anxiety, and } \\
\text { depression can }\end{array}$ & $\begin{array}{c}{[143][144][} \\
145]\end{array}$ \\
\hline
\end{tabular}




\begin{tabular}{|c|c|c|c|c|}
\hline & $\begin{array}{l}\text { the hormonal } \\
\text { imbalance, and } \\
\text { non- } \\
\text { communicable } \\
\text { disease }\end{array}$ & & be reduced & \\
\hline \multirow{7}{*}{ Old } & $\begin{array}{l}\text { Depletion of } \\
\text { zinc status }\end{array}$ & $\begin{array}{l}\mathrm{Zn} \text { supplementcan be } \\
\text { taken into account to } \\
\text { build immunity }\end{array}$ & $\begin{array}{l}\text { Blocks the } \\
\text { replication of } \\
\text { SARS CoV-2 } \\
\end{array}$ & [146] [147] \\
\hline & $\begin{array}{c}\text { Lower oxygen } \\
\text { level }\end{array}$ & $\begin{array}{c}\text { Iron-rich food along } \\
\text { with vitamin } \mathrm{B} 6 \text { rich } \\
\text { foodshould be } \\
\text { consumed in proper } \\
\text { portion }\end{array}$ & $\begin{array}{l}\text { Assists to level } \\
\text { up oxygen level }\end{array}$ & [148] \\
\hline & $\begin{array}{l}\text { Lower level of } \\
\text { Vitamin D }\end{array}$ & $\begin{array}{c}\text { Omega-3 along with } \\
\text { Protectin D1, vitamin } \\
\text { D and calcium, vitamin } \\
\text { E, magnesium, folate } \\
\text { can be supplemented as } \\
\text { they all are interlinked } \\
\text { to each other and } \\
\text { increase vitamin D } \\
\text { status }\end{array}$ & $\begin{array}{c}\text { Reduces } \\
\text { mortality rate } \\
\text { through } \\
\text { mitigating age } \\
\text { related } \\
\text { complications }\end{array}$ & $\begin{array}{c}{[149][154] .} \\
{[155]}\end{array}$ \\
\hline & Dietary Fibers & $\begin{array}{l}\text { Soluble fibers found in } \\
\text { oats, barley, peas, } \\
\text { apples, citrus fruits, } \\
\text { and potatoes as well, } \\
\text { Chemically engineered } \\
\text { sulfated glucans }\end{array}$ & $\begin{array}{l}\text { Mitigate their } \\
\text { constipation and } \\
\text { shows strong } \\
\text { antiviral } \\
\text { activities }\end{array}$ & $\begin{array}{c}{[150]} \\
{[151][152]} \\
{[153] .}\end{array}$ \\
\hline & $\begin{array}{c}\text { Vitamin } \\
\text { deficiencies }\end{array}$ & $\begin{array}{c}\text { Supplementation } \\
\text { through Vitamin C, } \\
\text { Vitamin E, } \\
\text { megavitamin D3 dose } \\
\text { therapy }\end{array}$ & $\begin{array}{l}\text { Used to treat } \\
\text { patients during } \\
\text { SARS } \\
\text { epidemicto } \\
\text { stimulate } \\
\text { immunity }\end{array}$ & [73] [147] \\
\hline & $\begin{array}{c}\text { Abnormal } \\
\text { Vitamin E and } \\
\text { Vitamin D status } \\
\text { allow frequent } \\
\text { infections }\end{array}$ & $\begin{array}{l}\text { Vitamin D, Vitamin C, } \\
\text { Zinc, and Echinacea in } \\
\text { combination must be } \\
\text { taken on a regular basis }\end{array}$ & $\begin{array}{l}\text { Worked better in } \\
\text { common cold }\end{array}$ & [156] [157] \\
\hline & Others & $\begin{array}{l}\text { Tannins } 3 \text { times daily } \\
\text { as tea or from fruits }\end{array}$ & $\begin{array}{l}\text { Safe and highly } \\
\text { effective } \\
\text { antiviral reagents }\end{array}$ & [158] [159] \\
\hline
\end{tabular}




\section{Dietary Characteristics}

1) Inavailability of nutrient rich food 2) Changes of dietary pattern and more prone to take processed food 3) Malabsorption and maldigestion of food 4) Excessive Alcohol Consumption
Socioeconomics Characteristics

1) Low Income

2) Lack of education

3) Improper knowledge, attitude and practice towards nutritious food intake
Environmental

Problems and Others

1) Pollution

2) Chronic Stress

3) Smoking

4) Lack of Physical exercise



Figure 1: Leading factors towards the higher risk of infection 


\section{Early Response} (Non Specific)

Natural killer cell Interferon

Nonspecific inhibition

\section{Immunity to Viral Infection}



\section{Specific resistance}

to reinfection

\section{Late Response}

(Specific response)

Humoral immunity

Cell mediated immunity

\section{Virus Induced Immunopathology}

Figure 2: Associated immune response of a virus infected person 